\title{
Cytotoxic Activity of Peronema canescens Jack Leaves on Human Cells: HT-29 and Primary Adenocarcinoma Colon Cancer
}

\author{
Arsyik Ibrahim ${ }^{1,2, *}$, Siswandono ${ }^{3}$, Bambang Prajogo EW $^{3}$
}

Arsyik Ibrahim ${ }^{1,2, *}$, Siswandono ${ }^{3}$, Bambang Prajogo EW ${ }^{3}$

'Doctoral Program, Faculty of Pharmacy, University of Airlangga, Surabaya 60115, East Java, INDONESIA.

2Department of Pharmaceutical Sciences, Faculty of Pharmacy, University of

Mulawarman, Samarinda 75119, East Kalimantan, INDONESIA.

${ }^{3}$ Department of Pharmaceutical Sciences, Faculty of Pharmacy, University of Airlangga Surabaya 60115, East Java, INDONESIA.

\section{Correspondence}

\section{Arsyik Ibrahim}

Doctoral Program, Faculty of Pharmacy, University of Airlangga, Surabaya 60115; Department of Pharmaceutical Sciences, Faculty of Pharmacy, University of

Mulawarman, Samarinda 75119, East Kalimantan, INDONESIA.

Phone no: +6281347912495

E-mail: achie.ibrahim@gmail.com

History

- Submission Date: 17-09-2021;

- Review completed: 28-09-2021

- Accepted Date: 06-10-2021.

DOI : 10.5530/pj.2021.13.176

Article Available online http://www.phcogj.com/v13/i6

Copyright

(C) 2021 Phcogj.Com. This is an open access article distributed under the terms of the Creative Commons Attribution 4.0 International license.

\begin{abstract}
Background: In Indonesia, this species was well known in Sumatera, Kalimantan, Java, and Sulawesi Peronema canescens Jack (Sungkai) was traditionally used as an anti-flatulent, fever, toothache. Sungka leaves contain many secondary metabolites with potential anticancer activity. The reported anticancer research was still limited to the cytotoxic activity of chloroform extract on the HT-29 colon cancer cell line. However, it was necessary to uncover the underlying mechanism. Aim: The purpose of this study was to investigate the mechanism (such as cell cycle inhibition, induces cells apoptosis, and necrosis) of subfraction chloroform (SF3) from P. canescens extract has anticancer activity on HT-29 cells and primary Adenocarcinoma (AdenoCa pT3N1cM1) colon cancer cells. Materials and Methods: The extraction by maceration method using methanol solvent, the fractionation process was using vacuum column chromatography (VCC) with polarity gradient eluent. The cytotoxicity of SF3 was measured by MTT assay. The cell cycle inhibition, apoptosis induction, and necrosis cells were evaluated with the Flow cytometry method. Results: Cytotoxicity value $\left(\mathrm{IC}_{50}\right)$ against AdenoCa cells was $1.897 \mu \mathrm{g} / \mathrm{ml}$. The inhibition activity of synthesis and mitosis phase in cell cycle demonstrated that the different concentrations of SF3 have inhibition activity on HT-29 $(29.614 \mu \mathrm{g} / \mathrm{ml})$ of $26.79 \%$ and $0.16 \%$, AdenoCa cells $(14.807 \mu \mathrm{g} / \mathrm{ml})$ of $10.27 \%$ and $19.29 \%$, respectively. For induced apoptosis activity on HT-29 $(29.614 \mu \mathrm{g} / \mathrm{ml})$ and AdenoCa cells $(14.807 \mu \mathrm{g} / \mathrm{ml})$ were $26.58 \%$ and $11.50 \%$, successively. Whereas, necrosis activity on HT-29 $(29.614 \mu \mathrm{g} /$ $\mathrm{ml}$ ) and AdenoCa cells $(14.807 \mu \mathrm{g} / \mathrm{ml})$ were $0.02 \%$, and $9.56 \%$, respectively. Conclusion: The subfractions chloroform (SF3) of $P$. canescens extract has potential activity on HT-29 and Adenocarcinoma cells through cell cycle inhibition, induces apoptosis and necrosis cells.
\end{abstract}

Key words: Apoptosis, Cell cycle, Colon cancer cells, Necrosis, Peronema canescens Jack.

\section{INTRODUCTION}

Cancer is a group of cells characterized by uncontrolled and abnormal cell growth. Cancer cells can invade other tissues and perform metastases. ${ }^{1-3}$ Colorectal cancer occurs in the rectum, initially as a polyp in the large intestine or rectum, called adenocarcinoma. ${ }^{4}$ In addition to synthetic product cancer drugs, natural products containing secondary metabolites as chemopreventive: anticarcinogenic and anti-mutagenic, which work by inhibiting the development of cancer cells, such as flavonoids, alkaloids, terpenoids, and phenolics. ${ }^{5,6}$ Peronema canescens Jack is the only species in the genus Peronema, family Verbenaceae, is a tree that grows in tropical areas: Indonesia, Thailand, and Malaysia. ${ }^{7}$ Several studies from the Verbenaceae family are active in colon cancer (HCT-15) cell lines, such as Vitis Fructus and Vitex trifolia. ${ }^{8,9}$ Phytochemical investigations from $P$. canescens had isolated biologically active compounds including $\beta$-sitosterol, phytol, $\beta$-amyrin, peronemin A1, A3, $\mathrm{B} 2, \mathrm{~B} 2, \mathrm{~B} 3, \mathrm{C} 1$, and $\mathrm{D} 1$, peronemin $\mathrm{A} 3$ and $\mathrm{C} 1$ are antimalarial, also contain secondary metabolites: alkaloids, terpenoids, steroids, flavonoids, phenolics, and saponins. ${ }^{10-12}$ This compound was a cytotoxic component that inhibits cancer., ${ }^{5,13}$ Empirically, in Indonesia, Peronema leaf known as 'Sungkai' are traditionally us, especially the Dayak tribe of East Kalimantan used as medicine toothache, ringworms, anti-flatulence, and fever. ${ }^{12}$ Research has reported bioactivity with the Brine Shrimp Lethality Test (BSLT) method using methanol, hexane, and ethyl acetate extracts with shrimp larvae animal models. ${ }^{14}$ It was also known to have antibacterial, antioxidant, antipyretic, immuneboosting, and antidiabetic activities. ${ }^{15-17}$ In addition, the chloroform subfraction extract was reported to have a cytotoxic effect on HT-29 colon cancer cells. ${ }^{18}$

However, it was very important to add further scientific evidence regarding the anticancer activity of the chloroform subfraction of this plant before the active chemical compounds are isolated. Hence, this study continued previous studies with the expansion of testing on primary colon cancer cells and was the first report of in vitro anticancer of $P$. canescens extract through inhibition of cell cycle, apoptosis, and necrosis HT-29 cells and primary colon cancer cells AdenoCa pT3N1cM1.

\section{MATERIALS AND METHODS}

\section{Materials and Equipment}

The sample of $P$. canescens leaf was obtained in Tanah Merah Sub-District, Samarinda, East Kalimantan, in May 2019. It was stored at Pharmaceuticals Research and Development Laboratory of FARMAKA TROPIS, Faculty of Pharmacy Mulawarman University East Kalimantan, Indonesia. It was determined at the Dendrology and Forest Ecology Laboratory of the Faculty of Forestry, Mulawarman University, Samarinda. The voucher specimen (33/ H17.4.1.08/LL/VI/.2011). In this study, the chemical materials were used included: methanol p.a, hexane p.a, chloroform p.a, ethyl acetate p.a, ethanol pa 
(Merck, Indonesia), 5-Fluro uracil (Adrucyl ${ }^{\oplus}$, Indonesia), Chemicals and all other standard reagents purchased from Sigma Chemical Company (St Louis, MO, USA). PBS (Biomatic, Canada. The USA). Dimethyl Sulfo Oxide (DMSO) (Biomatic, Canada, USA). Fetal bovine serum and Trypsin-EDTA solution from Sigma Chemical Company (St Louis, MO, USA). DMEM, RPMI (Gibco BRL, Life Technologies, USA), 1\% Penicillin and Streptomycin (Meiji, Indonesia). MTT, Reagents Stopper sodium dodecyl sulfate 10\% (SDS, Merck ${ }^{\oplus}$, Darmstadt, Germany), Tissue Culture Flask $25 \mathrm{~cm}$ (Biologix Group Limited) Yellow tips, and Blue tips (Neptune, USA). Moreover, tools were used, including $\mathrm{CO}_{2}$ Incubator Galaxy $170 \mathrm{~S}$ (Eppendorf, Germany), laminar airflow (Biobase, Indonesia), and ELISA (Model 550, Bio-Rad, USA), Annexin V-FITC kit (Biolegend), Flow cytometer (BD FACS Lyric)

\section{Extraction Preparation}

According to a previous study, the extraction process was carried out using a macerator. ${ }^{18}$ Briefly, P. canescens leaves were dried and ground into a powder, then extracted with methanol, filtered with filter paper, and evaporated under vacuum to obtain a thick extract. The extract obtained was stored at room temperature until ready for fractionation using vacuum chromatography.

\section{Fractionation Process}

According to a previous study, the fractionation process was carried out using vacuum column chromatography (VCC) ${ }^{19}$ with some modification. Briefly, the extracted sample $(20 \mathrm{~g})$ was dissolved in hexane solvent, impregnated with $10 \mathrm{~g}$ silica gel G 20 - 50 mesh, homogenized. Samples were separated using VCC with silica gel G 70 $-230 \mathrm{mesh}$, column size $13 \mathrm{~cm}$, height $24 \mathrm{~cm}$, and $1000 \mathrm{ml}$ of polarity gradient eluent, respectively: hexane, chloroform, ethyl acetate, and ethanol. Then refraction was carried out with the same treatment as in the fractionation section, $10 \mathrm{~g}$ of the chloroform fraction extract, impregnated with $5 \mathrm{~g}$ of silica gel $\mathrm{G}$ using a vacuum column measuring $4-5 \mathrm{~cm}$, and a polarity gradient ratio of $250 \mathrm{ml}$ of eluent: hexane: ethyl acetate, methanol (hexane, 90:10, 80:20, 70:30, 60:40, 50:50, $40: 60,30: 70,20: 80,10: 90$, methanol), respectively, the refraction was performed three times. Six subfractions were obtained for the detection of the TLC plate, which was visualized with a UV lamp at $254 \mathrm{~nm}$.

\section{Cell Preparation}

This study used both HT-29 and human primary adenocarcinoma (AdenoCa pT3N1cM1) colon cancer cells. These HT-29 cells were obtained from the Laboratory of Anatomy Pathology, Faculty of Medicine, University of Indonesia, and human primary AdenoCa pT3N1cM1 colon cancer cells obtained from the Cancer Virology and Pathobiology Research Center, Cipto Mangunkusumo National Hospital. The test cells were maintained in DMEM and RPMI 1640 supplemented with $10 \%$ FBS, added streptomycin and penicillin 100 $\mu \mathrm{g} / \mathrm{ml}$, incubated with $5 \% \mathrm{CO}_{2}$ at $37^{\circ} \mathrm{C}$. Both cells were treated with various extract concentrations for 24 hours. ${ }^{5,20}$

\section{Cell Viability Assay (MTT Assay)}

Cytotoxicity test carried out according to the method, ${ }^{5,21,22}$ with slight modification. Suspension of HT-29 and AdenoCa pT3N1cM1 cells, which were with a density of $1 \times 10^{6}$ cells $/ 100 \mu \mathrm{l}$, were inserted media into 96-well disc and incubated for $12 \mathrm{~h}$ in a $\mathrm{CO}_{2}$ incubator (N-Biotek). After $12 \mathrm{~h}$ of cell attachment, treated with SF3 extract $(1.563,3.125$, $6.25,12.5,25.0,50.0,100.0$ and $200.0 \mu \mathrm{g} / \mathrm{ml}$ ), and incubated for $24 \mathrm{~h}$. Next, $20 \mu$ of MTT reagent $(0.5 \mathrm{mg} / \mathrm{ml}$ in PBS) was added to each well and incubated at $37^{\circ} \mathrm{C}$ for $24 \mathrm{~h}$ in a $5 \% \mathrm{CO}_{2}$ humidified incubator. Cell condition examined by inverted microscopy. If formazan has formed after incubated for four $\mathrm{h}$, supernatant media was removed by adding dimethyl sulfoxide (DMSO) $(150 \mu \mathrm{l})$ to dissolve the formazan crystals in the cell, mixed for 2-3 min in the orbitals, incubated in a dark place at room temperature for $24 \mathrm{~h}$. Living cells react with MTT to form a purple color. The test results were read by ELISA (Model 550, BioRad, USA). Determined absorbance at $590 \mathrm{~nm}$. The $50 \%$ inhibitory concentrations $\left(\mathrm{IC}_{50}\right)$ of the $48 \mathrm{~h}$ are calculated with probit analysis (Product Solutions and Service Statistics (SPSS) 22.0 for Windows), with the formula:

\section{Flow Cytometry Assay}

Annexin test, using the Annexin V-FITC kit (Biolegend). Each cell sowed well $1 \times 10^{6}$ cells $/ 100 \mu$ in 5 well microcultures, incubated for 24 $\mathrm{h}$ in a $\mathrm{CO}_{2}$ incubator $\left(37^{\circ} \mathrm{C}, 5 \% \mathrm{CO}_{2}\right.$ humidity). The cells were treated with different concentrations of sample concentrations SF3 extract, 5-fluoro uracil (positive control), and DMSO 0.25\% (cell control). The cells were collected in a centrifuge tube, added $1 \mathrm{ml}$ of Phosphate Buffer Saline (PBS), $50 \mu$ lof $0.25 \%$ trypsin-EDTA for $3 \mathrm{~min}$. Cells were incubated for $24 \mathrm{~h}$ in a $\mathrm{CO}_{2}$ incubator at $37^{\circ} \mathrm{C}$. Added $1 \mathrm{ml}$ of culture media; the cells were washed three times with $2 \mathrm{ml}$ of PBS, centrifuged at $2000 \mathrm{rpm}$ for $3 \mathrm{~min}$. It was treated with a $100 \mu \mathrm{l}$ Annexin V-FITC and a $5 \mu \mathrm{l}$ PI kit. Incubation was carried out in a dark room for 1020 min, suspension with binding buffer, transferred into the FC tube using a nylon filter. Thereafter, the solutions were analyzed by a Flow cytometer (BD FACS Lyric). ${ }^{23}$

\section{RESULTS AND DISCUSSION}

\section{Extraction and Fractionation Process}

Extraction of solutes was based on differences in the chemical and physical properties of the solute (molecular weight, hydrophobic charge, polarity, and volatility) ${ }^{31}$ Extraction of the maceration method using methanol as a solvent; this method is suitable for use on soft textured samples. ${ }^{6,13}$ The sample fractionation process was carried out using vacuum column chromatography (VCC) ${ }^{19}$ with some modification. In this study, the sample was first impregnated with silica gel and then fractionated using a solvent gradient. The fractionation was carried out three times in a row using a gradient eluent ratio (hexane: ethyl acetate, methanol). As a result, six subfractions (SF1-SF6) were obtained (Table 1 ), which shows that the value of the weight of subfractions (SF) varies based on the difference in solvent gradient.

Polarity gradient elution was used to separate groups of compounds based on their solubility in suitable solvents. This method has the advantage that the separation of compound groups was faster based on their polarity level with the help of vacuum pressure..$^{32}$

\section{ANTICANCER ACTIVITY}

\section{Cytotoxicity Test MTTMethod}

MTT assay was used to measure viability and proliferation cells and acts on macrophage-mediated living mitochondria cells. ${ }^{5,23}$ The principle through the reaction of succinate dehydrogenase the tetrazolium salt was converted into purple formazan, measured by spectrophotometry after dissolving DMSO (Dimethyl Sulfo Oxide). ${ }^{24}$ According to a previous study, chloroform subfraction (SF3) extract of $P$. canescens leaves had cytotoxic activity on colon cancer cells HT-29. ${ }^{18}$ To develop research on the cytotoxic activity of SF3 extract on primary colon cancer cells. We conducted a follow-up study by testing the cytotoxic activity $\left(\mathrm{IC}_{50}\right)$ of SF3 extract on AdenoCa pT3N1cM1 colon cancer cells to complete the cytotoxic data SF3 of Sungkai leaves extract. The results of the MTT test showed that as the concentration of SF3 increased, cell viability decreased. Treatment of dose at $50 \mu \mathrm{g} / \mathrm{ml}$ reduces the viability cell by $16.141 \%$ of AdenoCa pT3N1cM1 cells. Meanwhile, the control of 5 -FU $(16 \mu \mathrm{g} / \mathrm{ml})$ dose reduces of AdenoCa pT3N1cM1 by $16.078 \%$ the cell viability; it shows a comparable toxicity effect (Table 2). 
Table 1: Weight of subfractions (SF) chloroform extract using polarity gradient ratio.

\begin{tabular}{|c|c|c|c|c|c|c|}
\hline \multicolumn{7}{|c|}{ Weight of chloroform subfraction extract (g) } \\
\hline Stage & SF1 & SF2 & SF3 & SF4 & SF5 & SF6 \\
\hline I & 1.356 & 1.363 & 1.559 & 2.279 & 2.321 & 1.237 \\
\hline II & 1.351 & 1.262 & 1.564 & 2.201 & 2.325 & 1.292 \\
\hline III & 1.245 & 1.354 & 1.423 & 2.276 & 2.232 & 1.252 \\
\hline Total & 3.952 & 3.979 & 4.546 & 6.756 & 6.878 & 3.781 \\
\hline
\end{tabular}

SF - Subfractions 1- 6

Table 2: Cytotoxic Effect of SF3 and 5-Fluorouracil on primary AdenoCa pT3N1cM1 cells.

\begin{tabular}{|cccc|}
\hline & SF3 & & \multicolumn{2}{c|}{ 5-FU } \\
\hline Concentration $(\mu \mathrm{g} / \mathrm{ml})$ & Cell viability $(\%)$ & Concentration $(\mu \mathrm{g} / \mathrm{ml})$ & Cell viability $(\%)$ \\
\hline 3.125 & 57.188 & 0.25 & 47.919 \\
6.25 & 30.076 & 0.5 & 38.651 \\
12.5 & 23.077 & 1.0 & 32.661 \\
25.0 & 19.105 & 2.0 & 27.491 \\
50.0 & 16.141 & 4.0 & 21.942 \\
100.0 & 9.899 & 8.0 & 19.483 \\
200.0 & 5.044 & 16.0 & 16.078 \\
\hline
\end{tabular}

SF3 - subfraction 3, 5-FU - 5-Fluorouracil
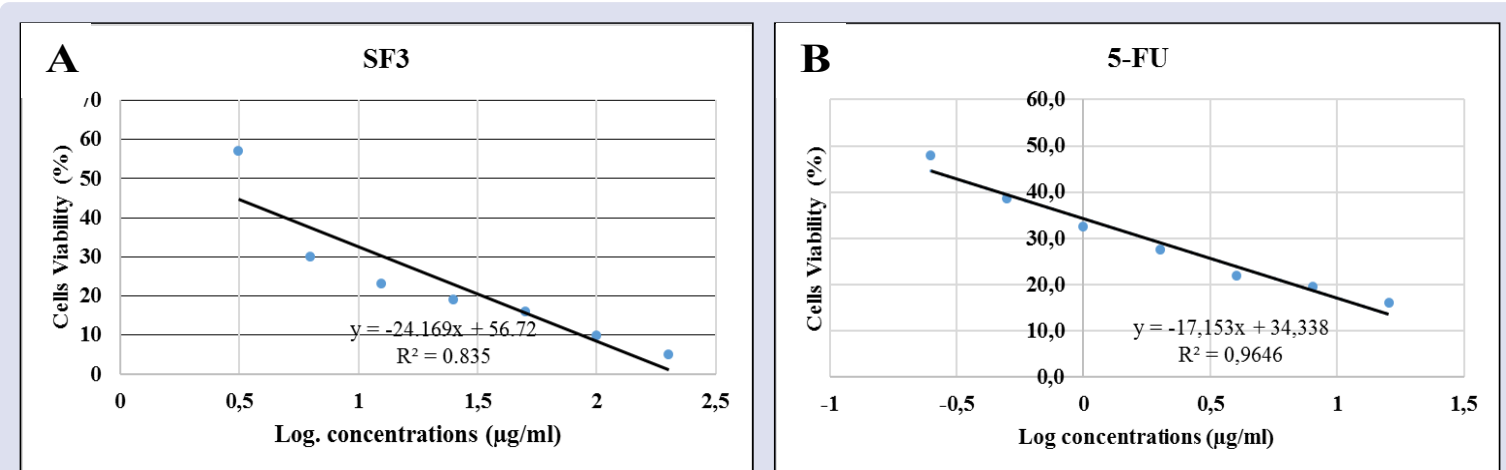

Figure 1: Graph of the linear regression between cells viability and log. concentration of the indicated samples: (A) Subfraction 3 (SF3) chloroform extract, (B). 5-Fluorouracil (control).

The results obtained in this study of the SF3 extract showed cytotoxic activity on AdenoCa pT3N1cM1 cells can be seen in Table 2. The $\mathrm{IC}_{50}$ value of SF3 extract and 5-FU against AdenoCa pT3N1cM1 cells can be determined based on the relationship between SF3 concentration and cell viability by linear regression, and obtained values $1.897 \mu \mathrm{g} / \mathrm{ml}$ and $0.122 \mu \mathrm{g} / \mathrm{ml}$, respectively (Figure 1 ).

The above results demonstrated that the cytotoxicity effect was categorized as a cytotoxic agent (any $\mathrm{IC}_{50}$ value less than $20 \mu \mathrm{g} / \mathrm{ml}$ was considered cytotoxic). The cytotoxicity criteria for the pure compound and crude extract were $\mathrm{IC}_{50}<20 \mu \mathrm{g} / \mathrm{ml}$ after $24 \mathrm{~h}$ of exposure. ${ }^{25}$ As a result, SF3 extract showed a significant cytotoxic potential against AdenoCa pT3N1cM1 cells and was weaker than the cytotoxic activity of 5-FU (positive control).

\section{Cell Cycle Analysis}

Plants were sources of herbal medicine and played an important role in the treatment and prevention of cancer. In this study, we developed an anticancer activity assay of SF3 chloroform extract from $P$. canescens leaves to determine the possible mechanism of action of SF3 anticancer on HT-29 and AdenoCa pT3N1cM1 cells using Flow cytometry. This tool analyzed changes in the cell cycle distribution (G0/G1, S, and G2/M) phases. The working method of this tool was fluorescenceactivated cell sorting with propidium iodide (PI) marker after $24 \mathrm{~h}$ of treatment. We demonstrated that SF3 inhibited the growth of HT-29 cells and AdenoCa pT3N1cM1 cells in a concentration-dependent and time-dependent manner.

Furthermore, our data reveal that SF3 induces termination of G0/G, S, and M/G2 phases in HT-29 cells and AdenoCa pT3N1cM1 cells. The arrest of the $S$ and M/G2 phases may be associated with DNA damage. ${ }^{26}$ The data cell cycle distribution and (G0/G1, S, and G2/M) phases in each concentration assay were shown in Figures 2 and 3.

The results of the study at a dose of $29.614 \mu \mathrm{g} / \mathrm{ml} \mathrm{SF} 3$ extract tested showed the highest cell cycle inhibitory activity in the synthesis (S) phase of $26.79 \%$, and mitosis (G2/M) phase of $0.16 \%$ (Figure 2), successively. Meanwhile, AdenoCa pT3N1cM1 cells $(14.807 \mu \mathrm{g} / \mathrm{ml})$ were $10.27 \%$ synthesis (S) phase and $19.29 \%$ mitosis (G2/M) phase (Figure 3) compared to control cells, and weaker than 5-FU (positive control).

\section{Inducing Apoptosis and Necrosis Cell}

A key strategy of cancer therapy was based on inducing apoptosis of cancer cells upon drug administration. ${ }^{23}$ An essential feature of chemopreventive agents was caused cell death by apoptosis rather than necrosis selectively. ${ }^{27}$ Cell morphology and DNA (Deoxyribonucleic acid) fragmentation are the leading indicators of apoptosis induction. ${ }^{28}$ Colon cancer cell programmed death can be detected due to exposure to chloroform subfraction (SF3) of $P$. canescens extract; evaluated 


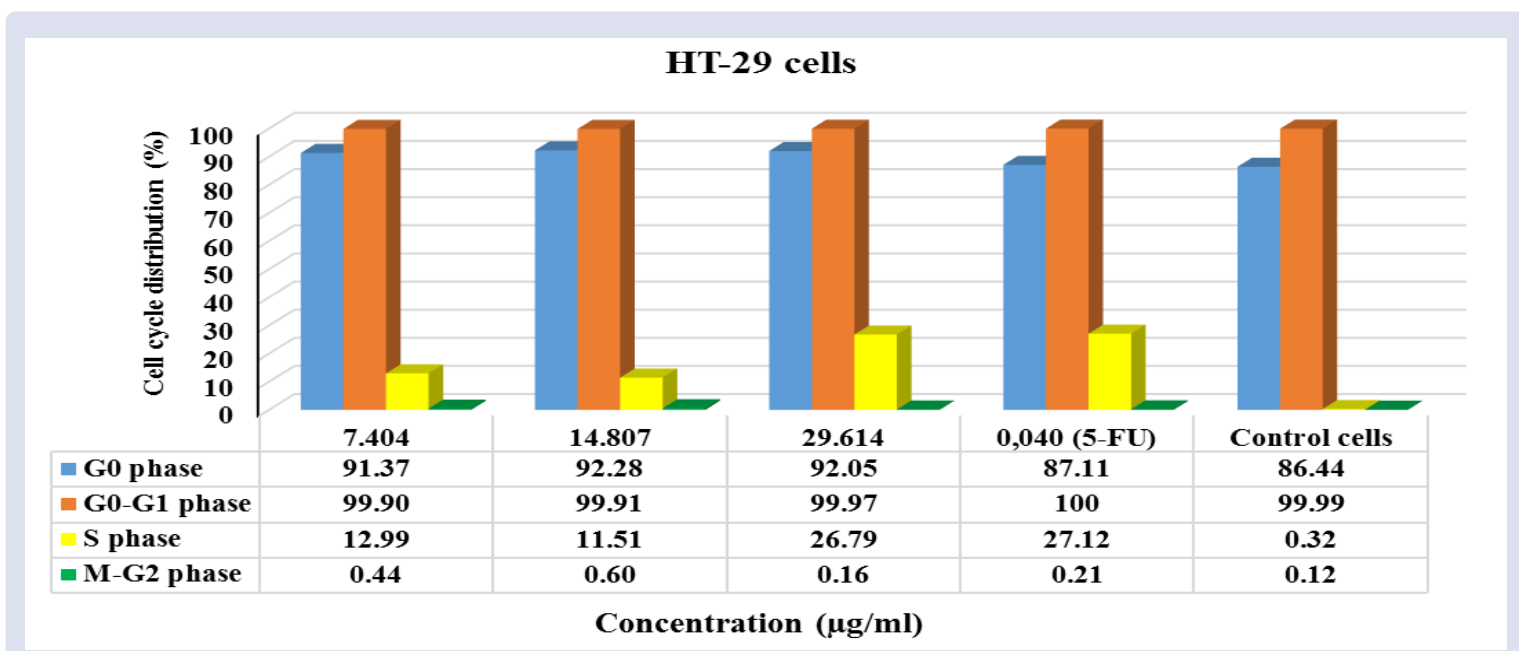

Figure 2: Effect of the concentration range of SF3 extract on the distribution phases of the cell cycle (G0, G0-G1, S, M-G2) on HT-29 cells.

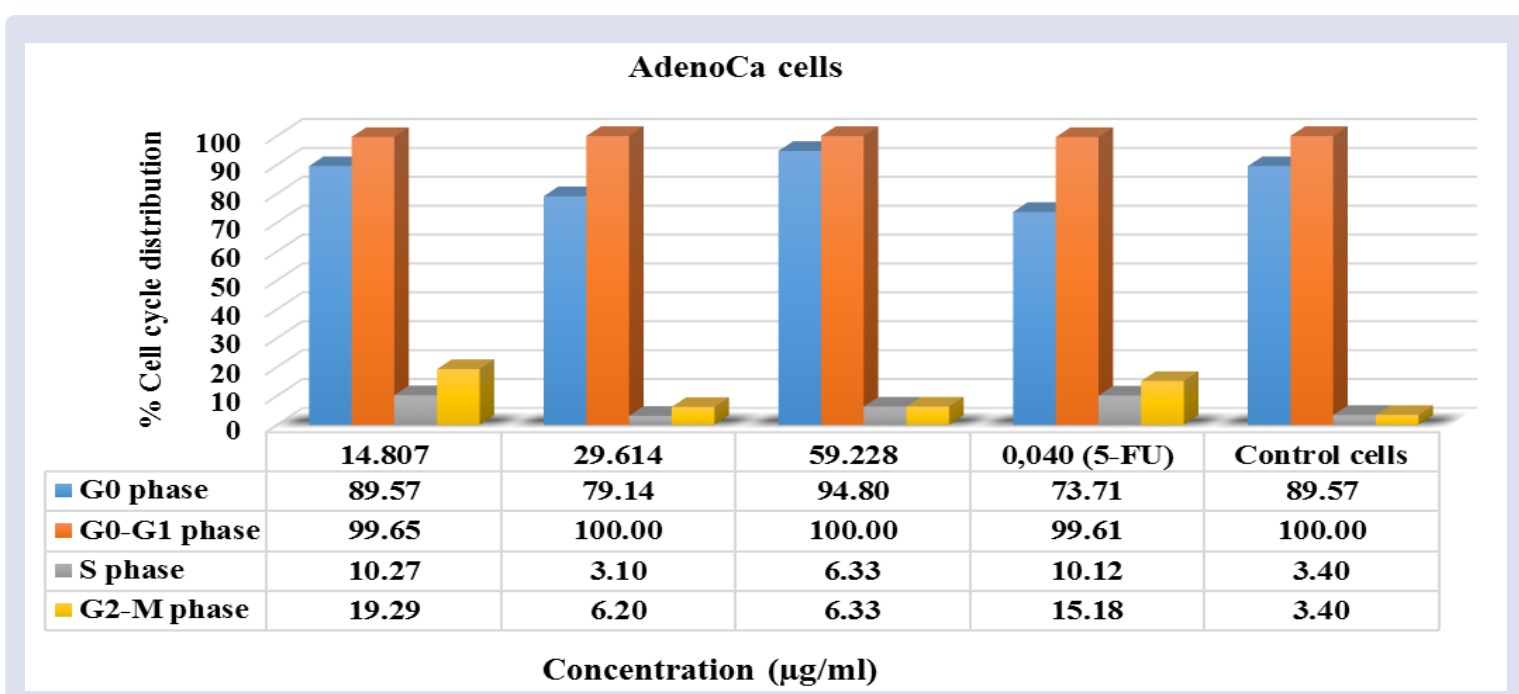

Figure 3: Effect of the concentration range of SF3 extract on the distribution phases of the cell cycle (G0, G0-G1, S, M-G2) on AdenoCa pT3N1cM1 cells.

Table 3: Effect of different concentrations of SF3 on the distribution value of apoptotic and necrotic cells.

\begin{tabular}{|cccccc|}
\hline \multirow{2}{*}{ Concentrations } & \multicolumn{5}{c}{ Distribution value (\%) HT-29 cells } \\
\cline { 2 - 6 } & LC & EA & LA & TA & Nec. \\
\hline $7.404 \mu \mathrm{g} / \mathrm{ml}$ & 86.83 & 12.73 & 0.26 & 12.99 & 0.18 \\
$14.807 \mu \mathrm{g} / \mathrm{ml}$ & 88.39 & 11.01 & 0.50 & 11.51 & 0.10 \\
$29.614 \mu \mathrm{g} / \mathrm{ml}$ & 73.40 & 26.44 & 0.14 & 26.58 & 0.02 \\
$5-\mathrm{FU} 0.040 \mu \mathrm{g} / \mathrm{ml}$ & 72.83 & 26.86 & 0.26 & 27.12 & 0.05 \\
Control & 99.65 & 0.23 & 0.01 & 0.24 & 0.10 \\
Concentrations & & Distribution value (\%) AdenoCa pT3N1cM1cells & Nec. \\
$14.807 \mu \mathrm{g} / \mathrm{ml}$ & LC & EA & LA & TA & 9.56 \\
$29.614 \mu \mathrm{g} / \mathrm{ml}$ & 98.94 & 9.77 & 3.73 & 11.50 & 3.10 \\
$59.228 \mu \mathrm{g} / \mathrm{ml}$ & 92.41 & 0.00 & 5.06 & 6.10 & 1.27 \\
$5-\mathrm{FU} 0.040 \mu \mathrm{g} / \mathrm{ml}$ & 83.66 & 1.27 & 9.34 & 10.51 & 5.84 \\
Control & 96.6 & 0.17 & 3.40 & 3.40 & 0.00 \\
\hline
\end{tabular}

LC- living cells, EA - Early apoptosis, LA - Late apoptosis, TA- Total apoptosis, Nec- Necrosis 
apoptosis and necrosis with Flow cytometry method using Annexin V-PI reagent. The study distribution of live cells, early apoptosis, late apoptosis, and necrosis can be seen in Table 3 .

Flow cytometry method with Annexin V and PI reagents works selectively to bind intact and fragmented cells so that it can differentiate among living cells, early apoptosis, late apoptosis, and necrosis. With Propidium Iodide (PI) reagent, cell death due to apoptosis or necrosis can be distinguished based on staining by intercalation with DNA. ${ }^{33}$ In the study, total apoptosis and necrosis activity value increased after the treatment dose of $2 \mathrm{IC}_{50}(29.614 \mu \mathrm{g} / \mathrm{ml}) \mathrm{SF} 3$ extract was $26.58 \%$, and necrosis was $0.02 \%$ on HT-29 cells (Tabel 3, Figure 4C). Whereas, treatment dose of $1 \mathrm{C}_{50}(14,807 \mu \mathrm{g} / \mathrm{ml})$ on AdenoCa pT3N1cM1 cells apoptosis and necrosis value were $11.50 \%$ and $9,56 \%$, respectively (Tabel 3, Figure 5A).

Meanwhile, 5-FU (positive control) test, the concentration $\mathrm{IC}_{50}(0.040$ $\mu \mathrm{g} / \mathrm{ml}$ ) showed apoptotic and necrotic effects of $27.12 \%$ and $0.05 \%$ on HT-29 cells, respectively, and for AdenoCa pT3N1cM1 cells were $10.51 \%$ and $5.84 \%$, successively. (Tabel 3, Figures 4D and 5D). The data from the analysis of total apoptosis of HT-29 cells representing the mean \pm SD of three replicates were analyzed by paired dependent sample T-test, showing a significant percentage value $\left({ }^{\star} \mathrm{P}>0.05\right)$ for a concentration of $29.614 \mu \mathrm{g} / \mathrm{ml}$ between the treatment control groups and nonsignificant $\left({ }^{*} \mathrm{P}<0.05\right)$ with 5 -FU (positive control) (Figure $6 \mathrm{~A})$. Whereas, AdenoCa pT3N1cM1 cells, the significant $\left({ }^{\star} \mathrm{P}>0.05\right)$ was at a concentration of $14,807 \mu \mathrm{g} / \mathrm{ml}$ between the treatment and control groups, and nonsignificant $\left({ }^{\star \star} \mathrm{P}<0.05\right)$ with 5 -FU (positive control) (Figure 6B).
In this study, 5-FU as a positive control was the primary chemotherapy agent used for colon cancer therapy. It is a prodrug produced by fluorouridine-5'-triphosphate (FUTP) metabolite, which affects the function of Ribonucleic acid (RNA) and fluoro-deoxy uridylate (FdUMP), inhibits Deoxyribonucleic acid (DNA) replication, induces p53 express $\mathrm{p} 21$ and $\mathrm{pRb}$ so that it can stop cell synthesis by accelerating apoptosis. . $^{29,30}$

The results showed that the chloroform subfraction (SF3) extract of $P$. canescens leaves had potential anticancer. This data was the first to be reported from the genus Peronema which inhibits the proliferation, apoptosis, and necrosis of colon cancer cells, which will help further research, especially the search for compounds from this plant as colon anticancer.

\section{CONCLUSIONS}

This study was the first to show the first to demonstrate the anticancer properties of $P$. canescens leaf chloroform SF3 extract on primary colon cancer cells HT-29 and AdenoCa pT3N1cM1 cells. It shows a lot exhibits multiple anticancer effects, including cell proliferation inhibition, cell cycle arrest, apoptosis, and necrosis cells. Therefore, this sample appears to be a valuable natural source of research and development for the treatment of colon cancer.

\section{ACKNOWLEDGMENT}

This study is supported financially by the Faculty of Pharmacy, Mulawarman University. The authors wish to thank Professor Laode Rijai, Dean of Faculty of Pharmacy, Mulawarman University, and
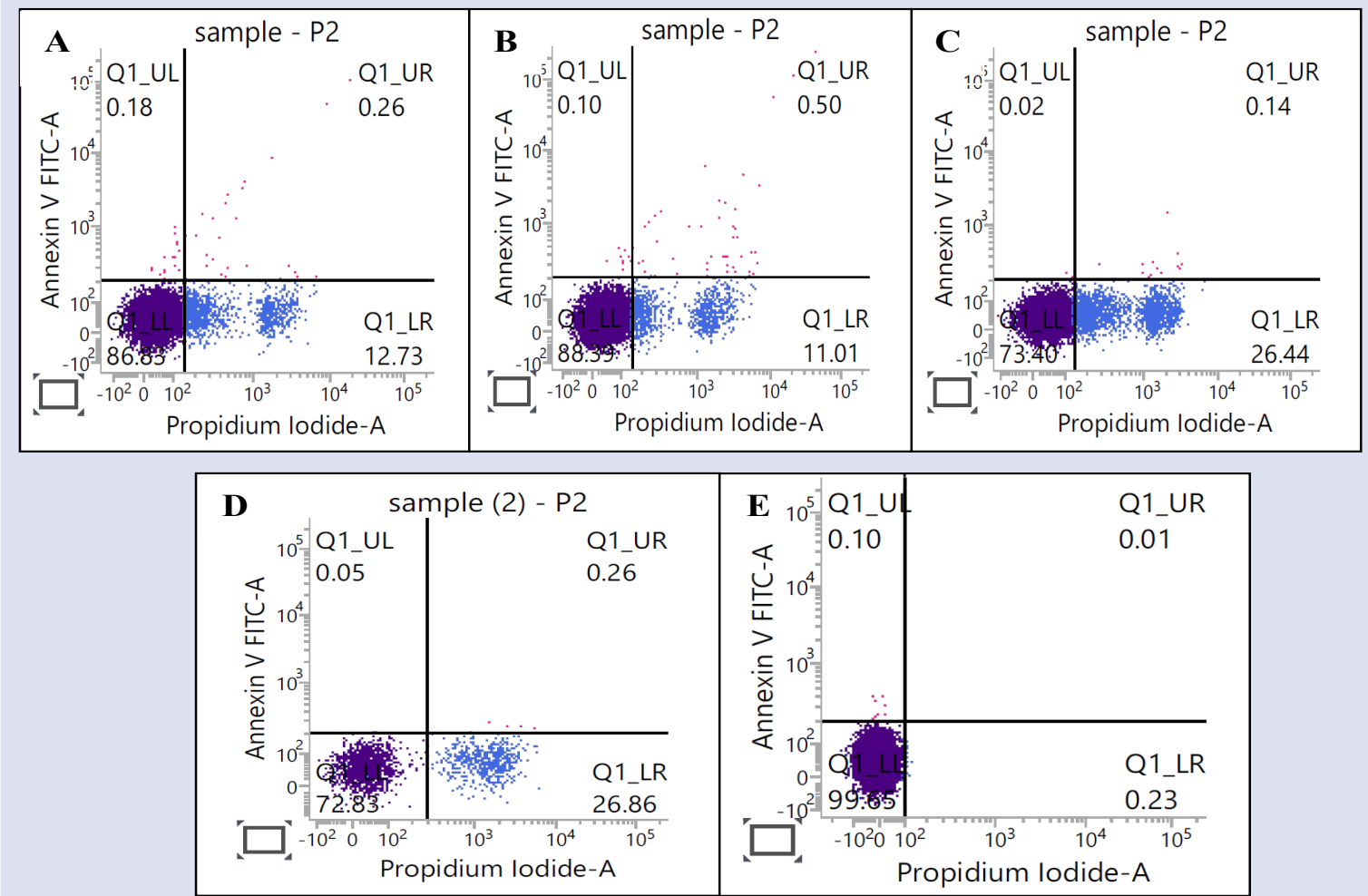

Figure 4: Effect of SF3 on apoptosis and necrosis of HT-29 cells. HT-29 cells were treated with different concentrations of SF3: (A) $7.404 \mu \mathrm{g} / \mathrm{ml}$ (1/2IC50), (B) $14.807 \mu \mathrm{g} / \mathrm{ml}$ (IC50), (C) $29.614 \mu \mathrm{g} / \mathrm{ml}$ (2IC50), (D) 5-FU $0.040 \mu \mathrm{g} / \mathrm{ml}$ (1/2IC50), (E) control cells for $24 \mathrm{~h}$. Four quadrants represent live cells (LL), early apoptosis (LR), late apoptosis (UR), and necrosis cells (UL), and incubated for 24 hours, respectively. 

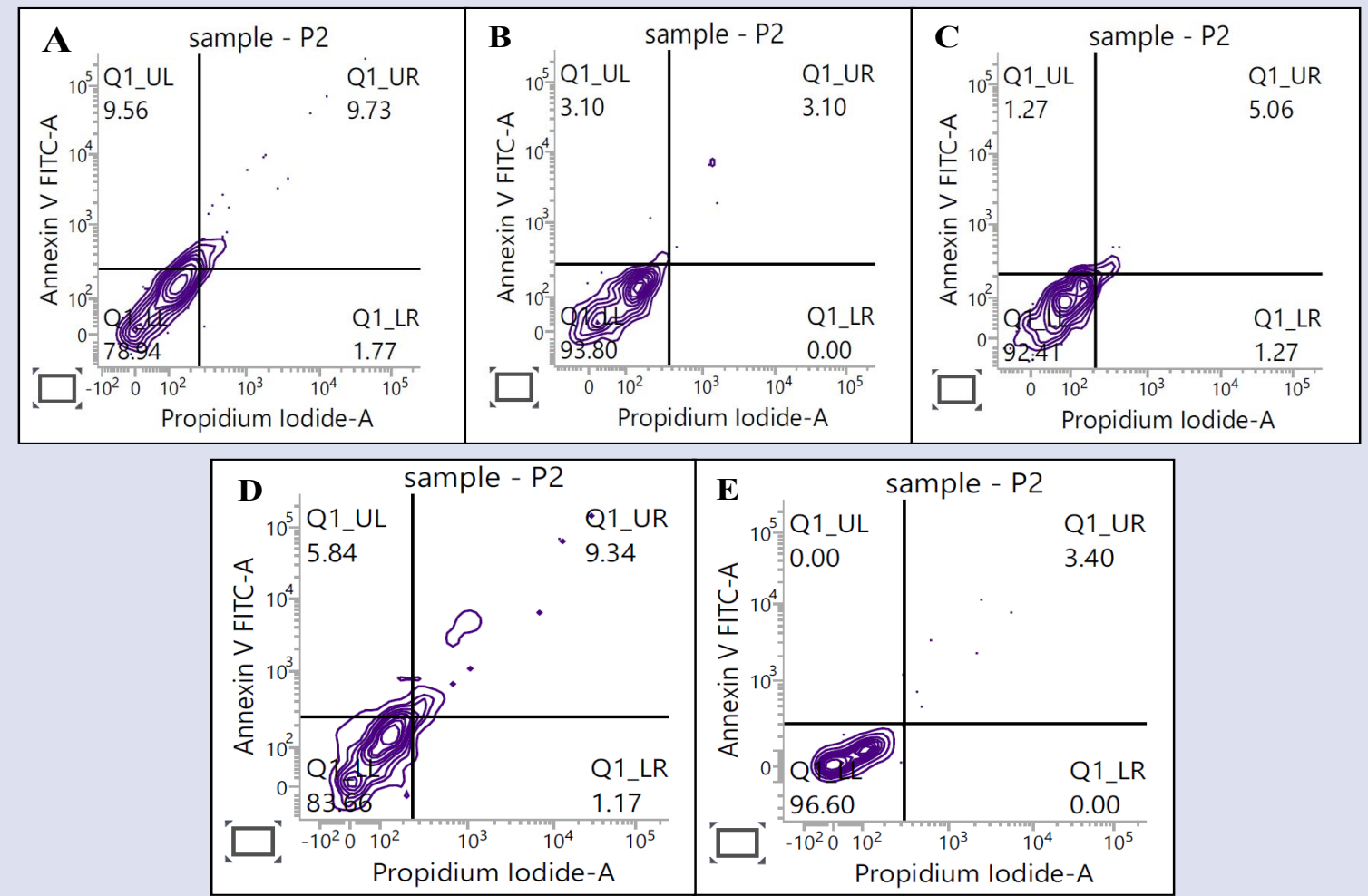

Figure 5: Effect of SF3 on apoptosis and necrosis of AdenoCa pT3N1cM1 cells. AdenoCa cells were treated with different concentrations of SF3: (A) $14.807 \mu \mathrm{g} / \mathrm{ml}$ (IC50), (B) $29.614 \mu \mathrm{g} / \mathrm{ml}$ (2IC50), (C) $59.228 \mu \mathrm{g} / \mathrm{ml}$ (4IC50), (D) 5 -FU 0.040 $\mu \mathrm{g} / \mathrm{ml}$ (1/2IC50), (E) control cell for $24 \mathrm{~h}$. Four quadrants represent live cells (LL), early apoptosis (LR), late apoptosis (UR), and necrosis cells (UL), and incubated for 24 hours, successively.
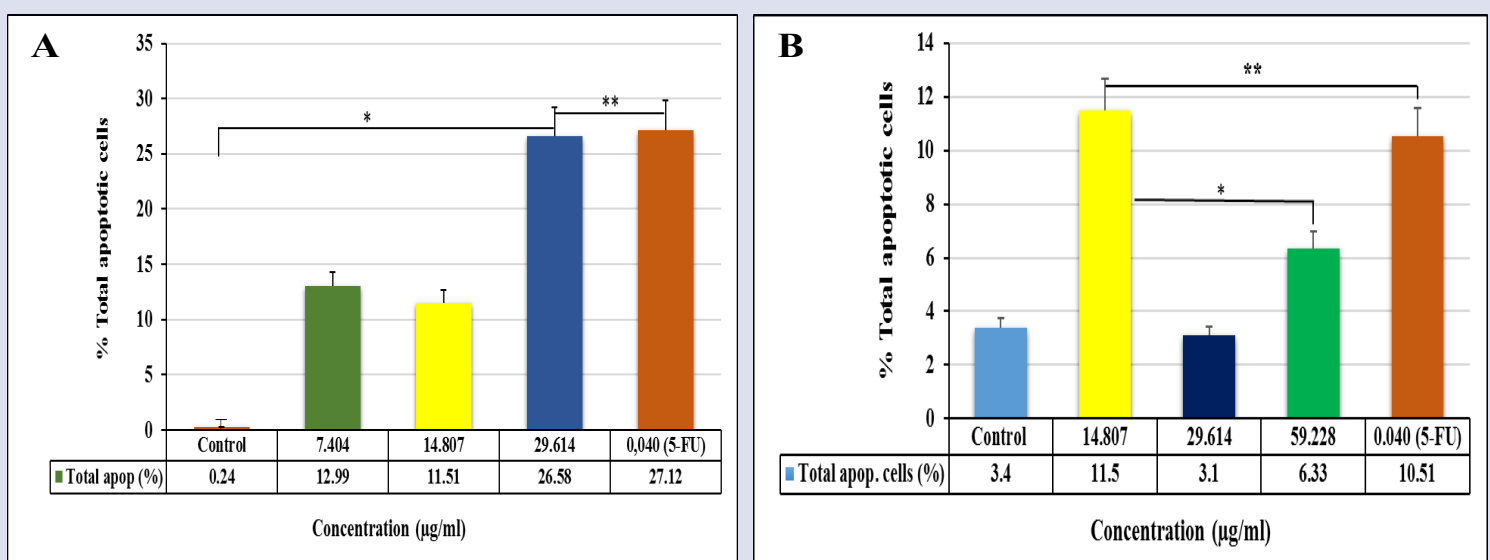

Figure 6: Concentration-dependent effect total apoptosis. (A) HT-29 cells were treated with different concentrations of SF3 (7.404, 14.807 and $29.614 \mu \mathrm{g} / \mathrm{ml}$ ) extract, and (B) AdenoCa pT3N1cM1 cells were treated with concentration of SF3 $(14.807,29.614$, and $59.228 \mu \mathrm{g} / \mathrm{ml})$ extract and positive control 5-FU $(0.040 \mu \mathrm{g} / \mathrm{ml})$ for 24 hours and total apoptosis was analyzed. Data representing mean \pm SD of three replicates were analyzed by dependent paired sample T-test. ${ }^{*} \mathrm{P}>0.05$ (significant); ${ }^{* *} \mathrm{P}<0.05$ (not significant) between the treatment and control groups.

grateful to Dr. Fadilah for facilities at the Laboratory of Anatomy Pathology, Faculty of Medicine, University of Medicine Indonesia.

\section{CONFLICTS OF INTEREST}

The authors declared no conflicts of interest.

\section{REFERENCES}

1. Dipiro JT, Talbert RL, Yee GC, Matzke GR, Wells BG, Posey LM. Pharmacotherapy: A pathophysiologic approach. 8th ed. New York; 2011.
2. Cancer.org. [homepage on the Internet]. American Cancer Society: Cancer Facts \& Figures 2021 [update 2021 July 24; cited 2021 August 20]. Available from: https://www.cancer.org/research/cancerfacts-statistics

3. Macdonald F, Ford CHJ, Casson AG. Molecular biology of cancer. 2nd ed. London and New York: BIOS Scientific Publishers; 2004

4. Cancer.gov. [homepage on the Internet]. National Cancer Institute: Colorectal Cancer [update 2021 August 24; cited 2021 September 2]. Available from: https://www.cancer.gov/types/colorectal. 
5. Fadilah F, Andrajati R, Yanuar A, Arsianti A. In-vitro anticancer activity combination of eugenol and simple aromatic benzoate compounds against human colon HCT-116 cells and WiDr cells. J Pharm Sci Res. 2017;9(5):637-41. Available from: https://www.jpsr.pharmainfo.in/ Documents/Volumes/vol9lssue05/jpsr09051720.pdf

6. Saifudin A. Senyawa alam metabolit sekunder teori, konsep dan teknik pemurnian. Ed. 1. Yogyakarta: Deepublish; 2014.

7. Tropical.theferns. [homepage on the Internet]. Tropical Plants. Peronema canescens Jack [update 2021 July 30; cited 2021 August 01]. Available from: https://tropical.theferns.info/query. php?full=Peronema+canescens

8. Hernandez MM, Heraso C, Villarreal ML, Vargas Al, Aranda E. Biological activities of crude plant extracts from Vitex trifolia L. (Verbenaceae). J Ethnopharm. 1999;67(1):44-37. doi: 10.1016/ s0378-8741(99)00041-0

9. Yao JL, Fang SM, Liu R, Oppong MB, Liu EW, Fan GW, et al. A review on the terpenes from genus vitex. Molecules. 2016;21(9):201. DOI:10.3390/molecules21091179

10. Kitagawa I, Simanjuntak P, Hori K, Nagami N, Taifo M, Shibuya $H$, Kobayashi M. Indonesian medicinal plants. VII. Seven new clerodanetype diterpenoids, peronemins A2, A3, B1, B2, B3, C1, and D1, from Peronema canescens (Verbenaceae). Chem Pharm Bull. 1994;42(5):1050-5. DOI: 10.1248/cpb.42.1050

11. Harmida H, Sarno S, Yuni V. Studi etnofitomedika di desa Lawang agung kecamatan Mulak ulu kabupaten Lahat Sumatera Selatan. J Penelit Sains. 2011;14(1):287-268. doi: I: https://doi.org/10.26554/ jps.v14i1.126

12. Ibrahim A, Kuncoro H. Identifikasi metabolit sekunder dan aktivitas antibakteri ekstrak daun Sungkai (Peronema canescens Jack.) terhadap beberapa bakteri patogen. J Trop Pharm Chem. 2012;2(1):18-8. doi: 10.25026/jtpc.v2i1.43

13. Yang H, Ping DQ. Targeting apoptosis pathway with natural terpenoids: implications for treatment of breast and prostate cancer. Curr Drug Targets. 2010;11(6):733-44. doi: 10.2174/138945010791170842.

14. Ahmad I, Ibrahim A. Bioaktivitas ekstrak metanol dan fraksi n-heksana daun Sungkai (Peronema canescens Jack) terhadap larva udang (Artemia salina Leach). J Sains \& Kes. 2015;1(3):114-9. doi: https:// doi.Org/10.25026/Jsk.V1i3.27.

15. Yani AP, Putranto AMH. Examination of the Sungkai's young leaf extract (Peronema canescens Jack) as an antipyretic, immunity, antiplasmodial, and teratogenicity in mice (Mus musculus). Int J Sci Eng. 2014;7(1):30-4. doi: https://doi.org/10.12777/ijse.7.1.30-34

16. Widodo H, Sismindari S, Asmara W, Rohman A. Antioxidant activity, total phenolic and flavonoid contents of selected medicinal plants used for liver diseases and its classification with chemometrics. J Appl Pharm Sci. 2019;9(6):105-99. doi: 10.7324/JAPS.2019.90614

17. Latief M, Sari PM, Fatwa LT, Tarigan IL, Rupasinghe HPV. Antidiabetic activity of Sungkai (Peronema canescens Jack) leaves ethanol extract on the male mice induced alloxan monohydrate. Pharmacol Clin Pharm Res. 2021;6(2):74-64. doi: 10.15416/pcpr.v4i3.31666.

18. Ibrahim A, Siswandono S, Prajogo BEW. Potential anticancer activities of chloroform subfraction from perineum leaf on colon cancer HT-29 cells In vitro. J Appl Pharm Sci. 2021; Accepted.
19. Vukovic NL, Obradovic AD, Vukic MD, Jovanovic D, Djurdjevic PM. Cytotoxic, proapoptotic and antioxidative potential of flavonoids isolated from propolis against colon (HCT-116) and breast (MDAMB-231) cancer cell lines. Food Res Int. 2018;106:80-71. doi: 10.1016/j.foodres.2017.12.056.

20. Abdullah M, Bela B, Syam AF, Simadibrata M, Melany S, Annisa F, et al. Establishment of primary 3D cell culture based on magnetic bioprinting for colorectal cancer cells from patients in Cipto Mangunkusumo National Hospital Indonesia. In: AIP Conference Proceedings [Internet]. 2019. p. 020025:6-1. Available from: https:// doi.org/10.1063/1.5125529.

21. Yao X, Lu B, Lü C, Bai Q, Yan D, Xu H. Taraxerol induces cell apoptosis through a mitochondria-mediated pathway in HeLa cells. Cell J. 2017;19(3):512-9. doi:10.22074/cellj.2017.4543.

22. Halimatushadyah E, Da'i M, Nursid M. Sitotoksisitas dan induksi apoptosis ekstrak etanol teripang Holothuria atra Jaeger, 1833 pada beberapa sel kanker. J Pasc. Pan. Biotechnol. Kelelautan dan Perikanan. 2018;13(2):101-9. doi: http://dx.doi.org/10.15578/jpbkp.v13i2.536.

23. Mutiah R, Widyawaruyanti A, Sukardiman S. Ethyl acetate fraction of Calotropis gigantea roots induce apoptosis through increased G2/M and increased expression of caspase-8 in colon cancer WiDr cell line. J Appl Pharm Sci. 2017;7(7):201-197. doi: 10.7324/JAPS.2017.70728.

24. Pitakpawasutthi $Y$, Suwatronnakorn M, Issaravanich S, Palanuvej C RN. In- vitro cytotoxic, genotoxic, and antityrosinase activities of Clitoria macrophylla root. J Adv Pharm Technol Res. 2021;12(1):13-8. doi:10.4103/japtr.JAPTR_94_20.

25. Geran RI, Greenberg NH, Macdonald MM, Schumacher AM, Abbott BJ. Protocols for screening chemical agents and natural products against animal tumors and other biological systems. Cancer Chemotherapy Reports. Vol. 3. 1972. p. 807.

26. Xiong Y, Wu X, Rao L. Tetrastigma hemsleyanum (Sanyeqing) root tuber extracts induces apoptosis in human cervical carcinoma Hela cells. J Ethnopharmacol. 2015;165:53-46. doi: 10.1016/j. jep.2015.02.030

27. Ouyang L, Shi Z, Zhao S, Wang FT, Zhou TT, Liu B, et al. Programmed cell death pathways in cancer: A review of apoptosis, autophagy, and programmed necrosis. Cell Prolif. 2012;45(6):487-98. doi:10.1111/ j.1365-2184.2012.00845.x.

28. Sudiana IK. Patobiologi Molekuler Kanker. Jakarta: Medica Salemba; 2011.

29. Longley DB, Harkin DP, Johnston PG. 5-Fluorouracil: Mechanisms of action and clinical strategies. Nat Rev Cancer. 2003;3(5):330-8. doi: 10.1038/nrc1074.

30. Levrero M, Laurenzi VD, Costanzo A, Sabatini S, Gong J, Wang JYJ, et al.The The p53/p63 /p73 family of transcription factors : Overlapping and distinct functions. J Cell Sci. 2000;113:1661-70.

31. Hyotylainen T, Wiedmer S. Chromatographic methods in metabolomics. 18 ed. UK: RSC Publishing; 2013. doi: https://doi. org/10.1039/9781849737272.

32. Susanti M, Dachriyanus. Kromatografi cair kinerja tinggi. Ed. 1. Padang: LPTIK, Universitas Andalas; 2017.

33. Zhang G, Gurtu V, Kain SR, Yan G. Early detection of apoptosis using a fluorescent conjugate of annexin v. Biotechniques. 1997;23(3):525531. doi: 10.2144/97233pf01. 


\section{GRAPHICAL ABSTRACT}

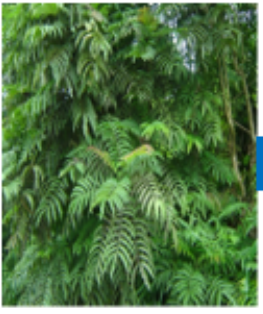

Peronema canescens Jack (Sungkai)

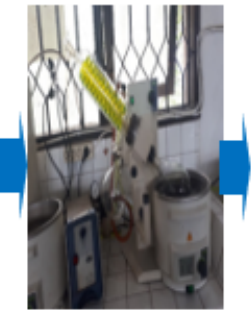

Extraction Process

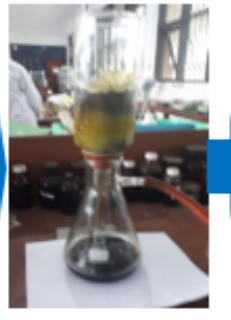

Fractionation Process

\begin{tabular}{|c|c|c|c|c|c|c|}
\hline \multicolumn{7}{|c|}{ Weight of chloroform fraction extract (30 g) } \\
\hline Stage & SF1 & SF2 & SF3 & SF4 & SF5 & SF6 \\
\hline I & 1.356 & 1.363 & 1.559 & 2.279 & 2.321 & 1.237 \\
\hline II & 1.351 & 1.262 & 1.564 & 2.201 & 2.325 & 1.292 \\
\hline III & 1.245 & 1.354 & 1.423 & 2.276 & 2.232 & 1.252 \\
\hline Total & 3.952 & 3.979 & 4.546 & 6.756 & 6.878 & 3.781 \\
\hline
\end{tabular}

Flow cytometry

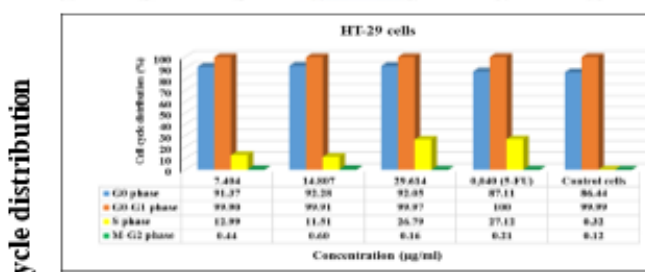
method

A

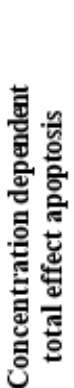

\section{$\mathbf{R}$}
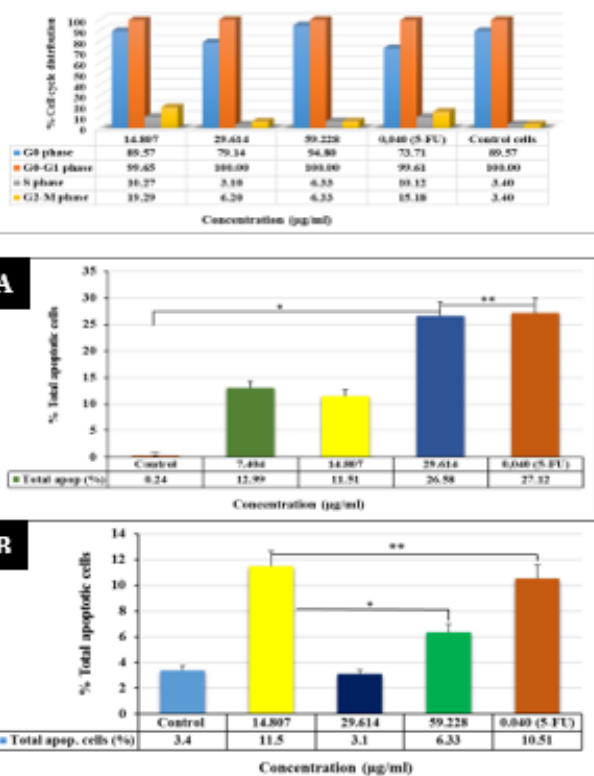

\section{ABOUT AUTHORS}

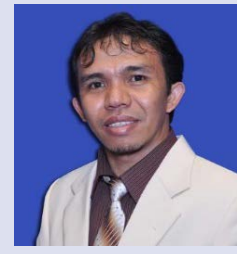

Arsyik Ibrahim, a lecturer and researcher at the Department of Pharmaceutical Sciences, Faculty of Pharmacy, Mulawarman University, East Kalimantan, Indonesia. He has experience in Pharmacognosy and Natural Products, working in the search and discovery of drugs from nature, identification, and screening of anti-cancer and antimicrobial active compounds.

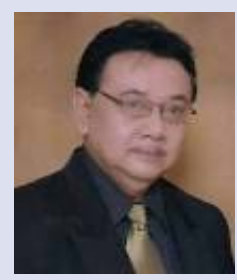

Siswandono is a Professor of Medicinal Chemistry at the Department of Pharmaceutical Sciences, Faculty of Pharmacy, Universitas Airlangga, Indonesia. Completed his Masters and Doctoral studies at the same Faculty. He has extensive experience in the field of Medicinal Chemistry and Drug Design. His expertise was focused on the design and development of drugs from synthetic compounds or bioactive natural products especially for anti-cancer agents and CNS depressants. Guiding students for Masters and Doctorate. He authored several Medicinal Chemistry books and has publications in International and National Journals.

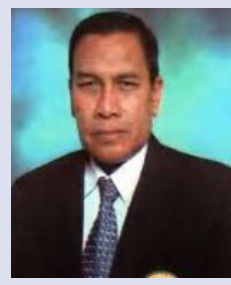

Bambang Prajogo E.W. is a Professor of Pharmacognosyat the Department of Pharmaceutical Sciences, Faculty of Pharmacy, Universitas Airlangga. He has vast experience in the area of Pharmacognosy, Natural products and Pharmacology. He has a publication in the National and International Journal. Through research, the Gandarusa plant as a male contraceptive drug received a world-class award (Y Prize Travel Award from The Y Prize Foundation 2014, Durham, North Carolina, United States). He developed male contraceptive products, authored several books, and has publications in National and International Journals. 